\title{
Field relations in the roof zone of the Ilímaussaq intrusion with special reference to the position of the alkali acid rocks
}

\author{
Agnete Steenfelt
}

\section{Introduction}

Most of the literature on the Ilímaussaq intrusion concerns various mineralogical, petrological, and geochemical aspects of the agpaitic suite of rocks. Less attention has been paid to the rocks of the roof zone, the granite and early syenites, which constitute a much smaller volume and which in many places have been affected by heavy alteration and weathering so as to obscure their interrelations.

The previous field studies of the roof zone (Ussing, 1912; Ferguson, 1964, 1970; Hamilton, 1964) led to contradictory conclusions regarding the number and order of intrusive events. Detailed field studies and mapping of selected areas were therefore undertaken by the author in 1969 and 1972 in order to contribute to the solution of the problems.

The most important conclusions from these studies have already been referred to (Blaxland et al., 1976; Nielsen \& Steenfelt, 1979), but the observations and a discussion of them have hitherto only appeared in an internal report (Steenfelt, 1972).

Considering the great efforts currently being spent on the geochemical evidence for the evolution of the Ilímaussaq intrusion it is felt justified to establish the field evidence that has to be taken into account in future models.

The present report contains a review of existing and new observations, with the main emphasis placed on the relations between the rock units. For descriptions of the rock types the reader is referred to Ussing (1912), Ferguson (1964, 1970) and Hamilton (1964).

Table 1 is a comparison of the terminology used by the author and by the authors quoted above.

\section{The augite syenite}

The augite syenite occurs along the southeastern, southern and western margins of the Ilímaussaq intrusion with vertical or steep contacts to the country rocks. In addition it forms a horizontal sheet in the roof zone northeast of Taseq. The augite syenite is chilled against the country rocks but shows no decrease in grain size towards the inner contacts against pulaskite, foyaite, and agpaites. Xenoliths of the augite syenite have been found in all other rock units of the intrusion, and all authors agree that the augite syenite represents the earliest introduction of magma.

The augite syenite has reacted chemically with the sandstone of the country rocks. Thus quartz is observed in apophyses of augite syenite into sandstone and around sandstone 
Table 1. Terminology of the Ilimaussaq roof zone rock units

\begin{tabular}{|c|c|c|c|}
\hline Present paper & Ussing 1912 & Ferguson 1964 & Hamilton 1964 \\
\hline augite syenite & augite-syenite & augite syenite & augite syenite \\
\hline alkali granite & arfvedsonite-granite & alkali granite & Ilfmaussaq soda granite \\
\hline alkali quartz syenite & quartz-syenite & quartz-syenite & quartz syenite \\
\hline pulaskite & pulaskite & pulaskite & (pulaskite) \\
\hline foyaite & foyeite & heterogeneous syenite & foyaite \\
\hline sodalite foyaite & sodalite-foyaite & sodalite foyaite & sodalite foyaite \\
\hline
\end{tabular}

Alkali acid rocks of this paper comprise alkali granite and alkali quartz syenite.

The hybrids of Ferguson (1964) comprise quartz syenite and pulaskite.

The pulaskite is regarded by Hamilton (1964) as a facies of the augite syenite.

xenoliths. In the latter case the augite syenite has assimilated sandstone even to the extent of reaching the composition of an alkali granite.

\section{Alkali acid rocks, pulaskite and foyaite}

These rock units occur in the roof zone of the complex, and their original extent has been much reduced by erosion. At present, remnants are found in five separate areas, fig. 1, which will be described individually.

Area I comprises foyaite and pulaskite. The occurrence was described by Ussing (1912) and mapped by Ferguson (1964). There is a gradual transition from the foyaite to the more or less horizontally overlying pulaskite which contains small xenoliths of augite syenite. Scree and gravel obscure the contact relations between the augite syenite and the foyaite, and although pulaskite has not been observed at the contact its presence cannot be excluded.

Area II, which comprises two remnants of a sheet of foyaite with inclusions of pulaskite and alkali acid rocks, was noticed and cursorily described by Ussing (1912), was mapped and described by Ferguson (1964, 1970), and remapped at a larger scale by the author (fig. 2). As the field relations in this area have presented some of the major problems regarding the position of the alkali acid rocks, they will be described here in detail.

The foyaite comformably overlies the sodalite foyaite and constitutes a sheet of some $50 \mathrm{~m}$ thickness. This is the thickest development of foyaite within the complex. The transition from sodalite foyaite to foyaite is gradual over a few metres, and locally dominated by pegmatitic stringers in both rocks. At the extreme southern end of the area a spectacular section of the foyaite is exposed. The lower part is composed of a sequence of 5 to 6 conformable pegmatite layers each about $1.5 \mathrm{~m}$ thick resting on top of each other. The pegmatites are zonal with a rusty lower zone with a relatively high proportion of mafic minerals, and an upper grey zone dominated by vertically arranged feldspar crystals attaining a length of 10-15 cm (photographs in Ferguson, 1964, p. 37). Such huge pegmatite layers have not been observed elsewhere in the foyaite.

The foyaite of the upper part of the sheet typically shows a foyaitic texture and continuous variations in the grain size from coarse to very coarse. Mineral graded layering frequently 
Fig. 1. Simplified map of the Ilímaussaq intrusion with location of areas described in the text.

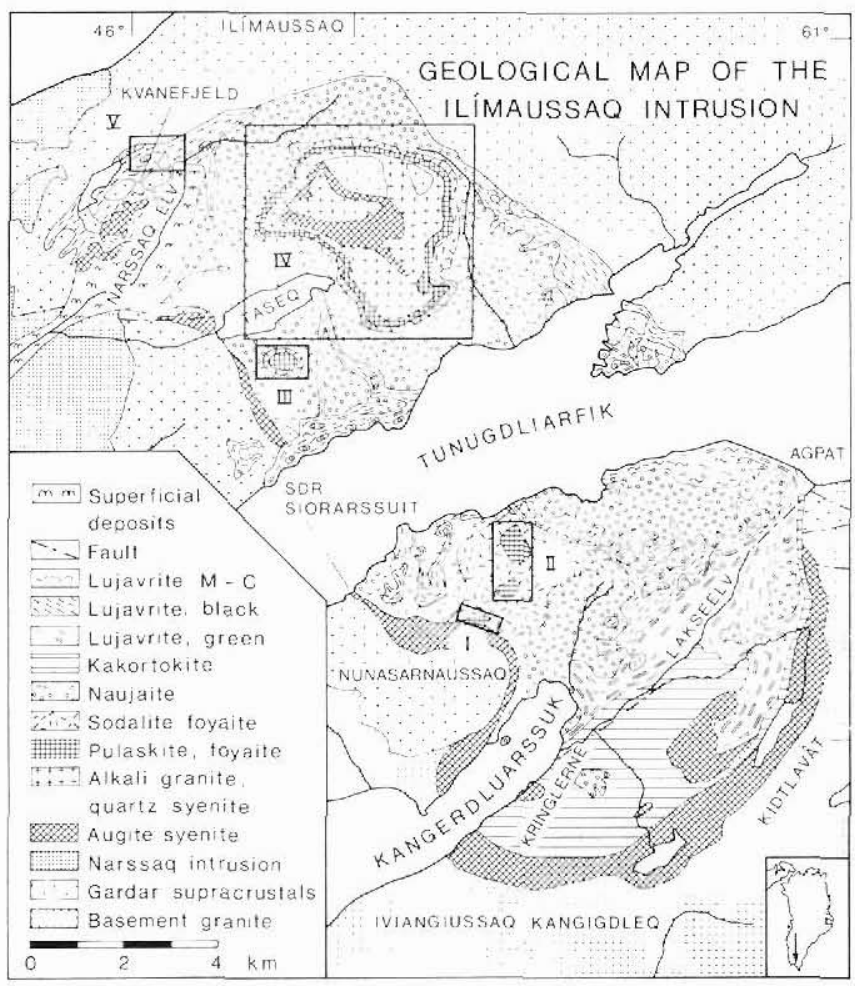

occurs. The $20 \mathrm{~cm}$ to $70 \mathrm{~cm}$ thick layered units are steeply inclined relative to the extension of the foyaite sheet.

Bodies of pulaskite and alkali acid rocks rest upon, or are enclosed by, the foyaite, as illustrated by the cross sections in fig. 2. Four types of inclusions are encountered: (1) lens-shaped bodies of pulaskite with inch-scale mineral banding, (2) small, rounded bodies of non-banded pulaskite, (3) small, rounded bodies of alkali granite, and (4) large, flat, composite bodies of alkali quartz syenite and banded pulaskite.

As seen on the map two small bodies of alkali granite are enclosed by pulaskite and three small bodies are enclosed by foyaite. As noted by Ferguson $(1970$, p. 111) these latter granite bodies are partly covered by the foyaite. The largest granite body ( $10 \mathrm{~m}$ across) is exposed on a slope and is seen to be completely surrounded by pulaskite. Usually a persistent snow cover prevents the observation of the lower limit of the granite body, a fact which may explain why Ferguson described the alkali granite occurrence as plug-like.

Surrounding the bodies of alkali granite a $0.5 \mathrm{~m}$ to $1 \mathrm{~m}$ wide 'halo' is developed in which pulaskite/foyaite has lost nepheline, is albitised, and may even contain quartz grains.

The relations between alkali quartz syenite, pulaskite and foyaite are well seen in the central part of the northern foyaite occurrence (fig. 2). The E-W cross-section of fig. 2 is verified by the $30 \mathrm{~m}$ high northwards-facing cliff that appears in the $\mathrm{N}-\mathrm{S}$ cross section. The two closely situated wedge-shaped bodies of alkali quartz syenite dip gently towards the north, but to a different degree, so that the top of the westernmost wedge dips below the 

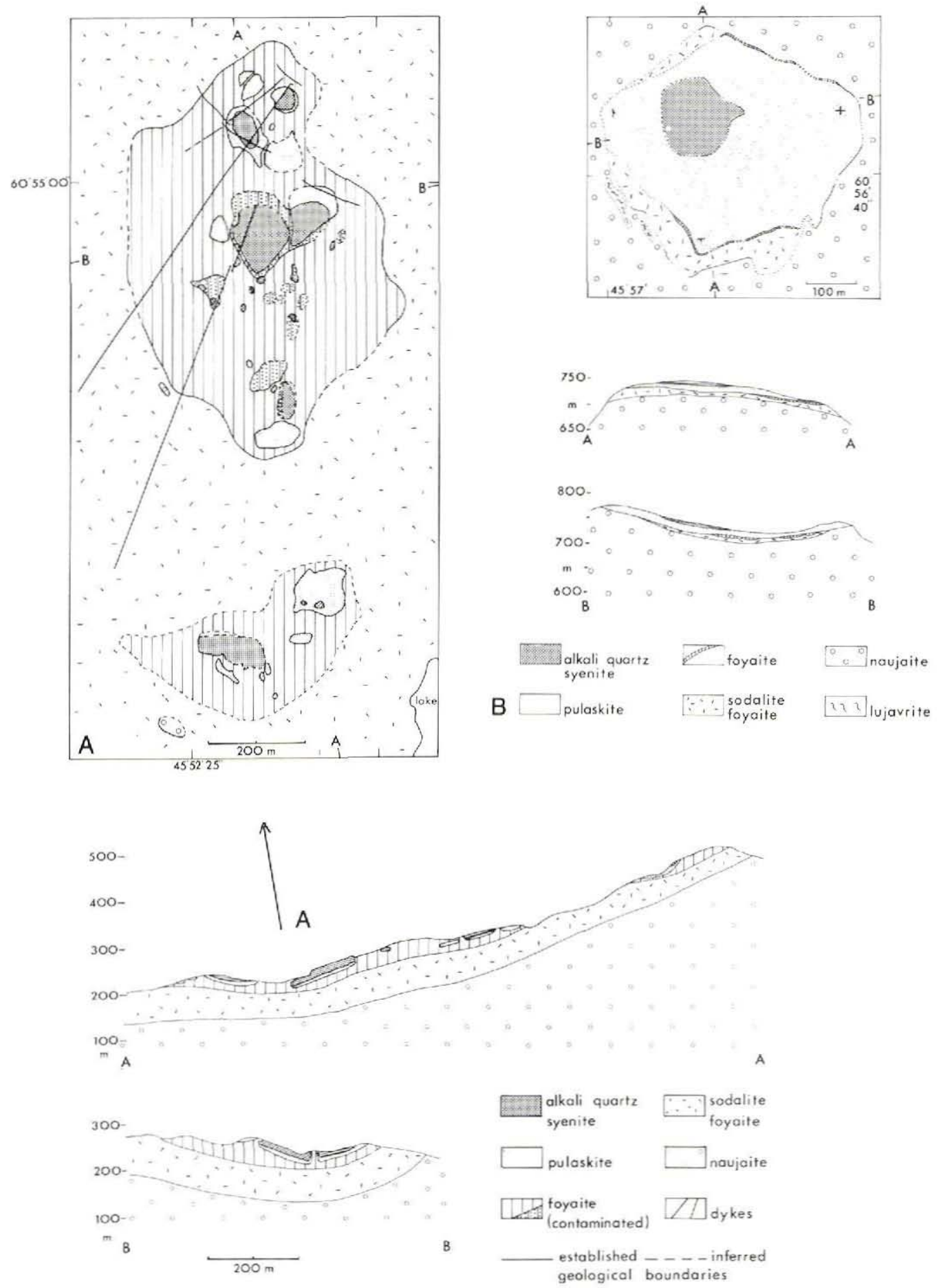

Fig. 2. Geological map and profiles of the root series of area II (A) and area III (B) in the Ilímaussaq intrusion. 
Fig. 3. A large xenolith of light grey pulaskite surrounded by foyaite which the person is standing on. From the southern part of area II.

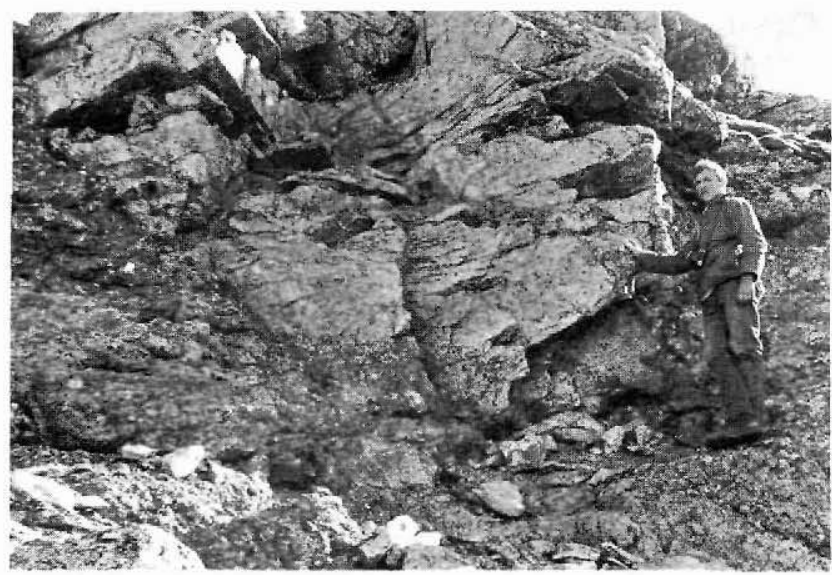

surface of foyaite while the bottom of the easternmost one is exposed (together with a substantial amount of pulaskite underlying the quartz syenite). Pulaskite is also developed as a $0.2 \mathrm{~m}$ to $0.5 \mathrm{~m}$ wide transition zone between the alkali quartz syenite and the foyaite along the vertical walls of the alkali quartz syenite bodies. Upwards the alkali quartz syenite bodies merge into foyaite without an intermediate zone of pulaskite, but with albitisation and the occasional presence of quartz in the contact facies of the foyaite.

The relations just described are typical for the composite inclusions. The alkali quartz syenite bodies are platy or lensoid and generally oriented subhorizontally. Inch-scale banded pulaskite, 1 to $10 \mathrm{~m}$ in thickness, invariably mantles the lower side of the alkali quartz syenite, and quartz-contaminated foyaite encloses the upper. The frequent albitisation at the surface in the central part of the foyaite sheet (fig. 2A) suggests the presence of more quartz syenite or granite below the surface.

Pulaskite forms separate inclusions in the foyaite besides mantling the alkali quartz syenite. Some of the inclusions are lens-shaped and display well developed inch-scale banding. These are thought to be remnants of composite inclusions. Other pulaskite bodies are rounded and have distinct contacts against the foyaite. They show no or weakly developed banding (fig. 3).

The scattered occurrence of the various types of inclusions, the differences in their shape, and their spatial position in the foyaite, led the author to regard them as xenoliths. The way the banding of the pulaskite conforms to the edges of the acid inclusions demonstrates that the latter were solid when the pulaskite crystallised. By analogy with the assimilation of sandstone xenoliths by the augite syenitic magma, the quartz contamination of the foyaite and the gradual transitions from foyaite or pulaskite to alkali acid rocks are taken to indicate that some assimilation of the acid xenoliths occurred. The significance of the interpretation of the field relations is treated in the discussion.

Area III (fig. 2) shows quite simple relations between the units of the roof zone, of which only the lowermost section is preserved. The area was studied by the author because earlier descriptions by Ferguson (1964) and Hamilton (1964) disagree.

The pulaskite forms a well defined saddle-shaped layer with a thickness of about $20 \mathrm{~m}$. Inch-scale mineral banding is rarely developed. The contact between pulaskite and the 
overlying quartz syenite is poorly exposed, but seems to be gradual. Foyaite is developed locally beneath the pulaskite, and sodalite foyaite only attains some thickness below the northward and southward sloping parts of the pulaskite layer. Otherwise patchy development of sodalite foyaite occurs within the foyaite. There are gradual transitions from sodalite foyaite through foyaite to pulaskite, whereas the boundary between pulaskite and naujaite is sharp. The naujaite has decreasing grain size towards the contact.

Area IV comprises the most voluminous and complete section of the roof zone. The c. 500 $\mathrm{m}$ thick layered sequence is, from the top downwards, composed of alkali granite, alkali quartz syenite, augite syenite, alkali quartz syenite, alkali granite, alkali quartz syenite, pulaskite, and foyaite grading into sodalite foyaite. Unfortunately the field relations are often obscured by extensive pneumatolytic alteration and by scree, as demonstrated by the dissimilarity in the appearance of the area on the published maps of Ussing (1912), Ferguson (1964) and Hamilton (1964). However, significant information on contact relations can be gathered from the descriptions made by these authors (summarised by Ferguson, 1970).

The augite syenite has intrusive contacts towards the volcanic country rocks and is itself intruded by alkali granite and alkali quartz syenite with development of a chilled margin in the latter (Hamilton, 1964, p. 50). The alkali granite is also intrusive into, and chilled against, the volcanic country rocks of the roof. The lower contact of alkali quartz syenite with pulaskite is transitional as in area III. The relatively thin layer of pulaskite is underlain by sodalite foyaite with a discontinuous development of foyaite in the boundary between them.

The field relations in the westernmost part of area IV are problematic and have been described differently by Ferguson (1964) and Hamilton (1964). The locality has been visited by the author, and as it is critical for the interpretation of the chronology it will be described as recorded in the field notes of 1969 and 1972.

"On the slope towards Nákâlâq the westernmost of the faults indicated on Ferguson's map (Ferguson, 1964) is met. The lowermost exposure shows a $10 \mathrm{~cm}$ wide lujavrite vein separating easily identifiable alkali quartz syenite and naujaite. Upwards the fracture zone widens and the lujavrite is emplaced in several parallel veins or fractures between angular inclusions of syenite and naujaite thus constituting an intrusion breccia. On the crest of the slope the fracture zone is rather wide and separates alkali granite from naujaite. Extensive areas of the naujaite are affected by natrolitisation and epidotisation."

"The eastern fault contact is exposed at altitude $935 \mathrm{~m}$ on the south slope. Heavily natrolitised naujaite is in contact with a $40 \mathrm{~cm}$ wide lujavrite vein on the other side of which occurs a foyaite-like rock grading into common quartz syenite over 2 to $3 \mathrm{~m}$. Centrally in the fault zone area the naujaite is easily recognisable."

By concluding that the naujaite is emplaced in a fault zone the author disagrees with Hamilton and Ferguson whose opinions are expressed in Ferguson (1970, p. 21): "Hamilton $(1964$, p. 58$)$ has reported that at a locality $1 \mathrm{~km}$ to the $\mathrm{N}$ of Taseq, the quartz syenite contains xenoliths of naujaite, sodalite foyaite and pulaskite and that locally the quartz syenite may in fact be granite. The author [Ferguson] has observed a large naujaite xenolith in granite at this locality; the naujaite was only identifiable by its characteristic texture; extreme hematite and fluorite alteration, faulting and scree cover make conclusive recognition of all local rock types very difficult". These authors both admit that they have not seen a direct contact between alkali granite and naujaite, and later on in his discussion of the 
Table 2. Order of intrusion of the different rocks of the Ilimaussaq massif according to investigations by various authors

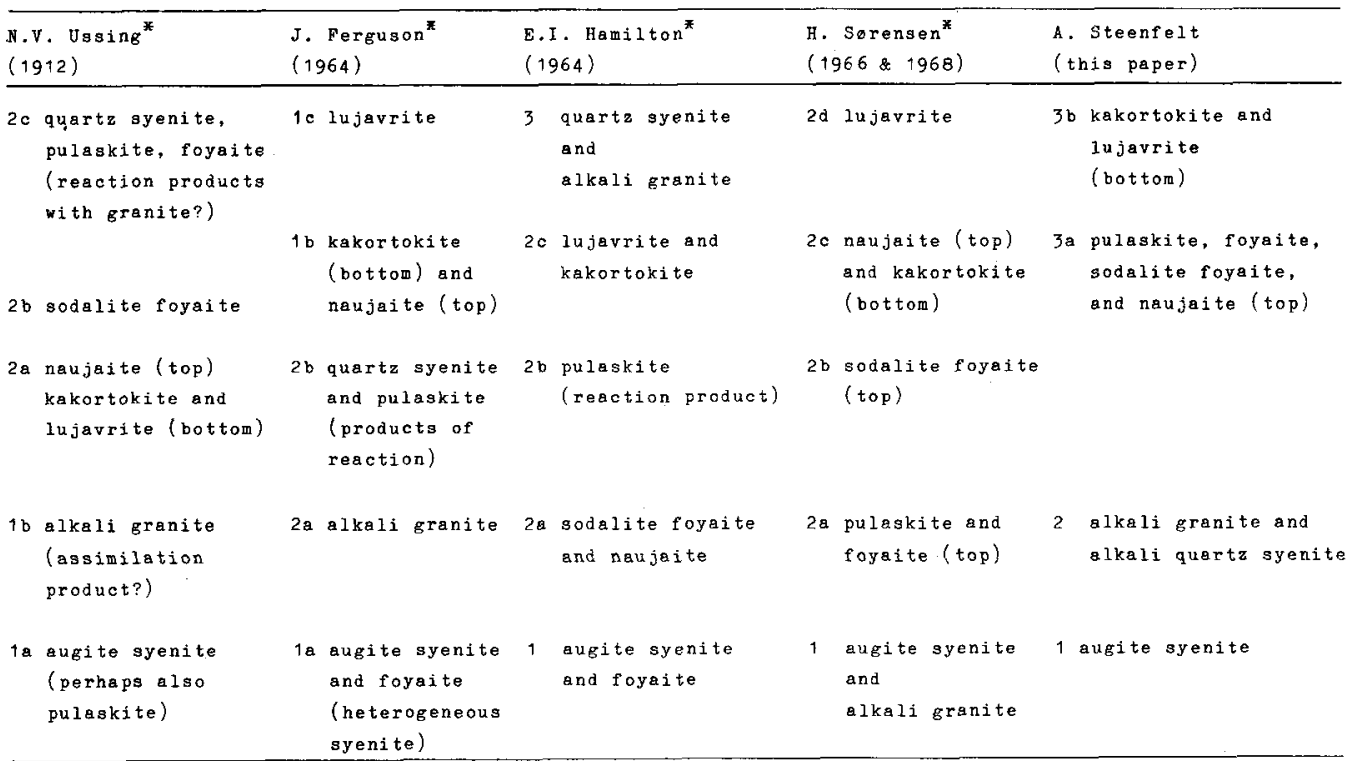

* From Sorensen (1970)

chronology Ferguson (1970, p. 111) suggests that the naujaite could have been faulted into its present position.

Area V, the Kvanefjeld plateau in the north-western corner of Ilimaussaq, has been studied by the author (Nielsen \& Steenfelt, 1979). Roof zone rocks comprise augite syenite, pulaskite, foyaite and sodalite foyaite occurring as xenoliths within lujavrite. Alkali acid rocks are absent in this area. The transition from pulaskite via foyaite to naujaite is exposed in one large xenolith. The pulaskite does not show inch-scale banding and shows a gradual transition to a $2 \mathrm{~m}$ thick layer of foyaite. The contact of the latter to the naujaite is sharp, and the sequence very much resembles the equivalent sequence in area III. As sodalite foyaite occurs in the vicinity as separate xenoliths, evidence is available for the existence of a 'normal' roof zone development from pulaskite to naujaite at Kvanefjeld prior to the intrusion of the lujavrite.

To the north-east of Kvanefjeld another occurrence of pulaskite to foyaite has been reported below the basalts of the roof (Rose-Hansen et al., 1976).

\section{Discussion}

The contradictory opinions on the number and order of intrusive phases in the Ilímaussaq complex are presented schematically in Sørensen (1970) and reproduced here in Table 2. With respect to the alkali granite, Sørensen (1970) states (p. 323 op. cit.) that the field relations of the alkali granite are still not solved. In his comprehensive discussion of the chronological sequence of crystallisation in the light of the field evidence, Ferguson (1970, p. 
111 ), in agreement with Sørensen, concludes that the relative ages of the acid intrusives and the agpaites are not incontrovertibly fixed. This statement has since been repeated in the majority of later publications on Ilímaussaq, most recently in Sørensen (1978, p. 19): "the position of this granite is still uncertain".

There are three main reasons for this uncertainty. The first is the discussion of the origin of the alkali acid rocks. The second is Ferguson's (1964) interpretation of the occurrences of alkali acid rocks in area II as sills and plugs, and the third is Hamilton's (1964) description of the naujaite 'xenolith' in area IV.

\section{The origin of the alkali acid rocks}

Owing to the formation of a liquid of alkali granitic composition in and around sandstone xenoliths in the augite syenite, it has been suggested (Ussing, 1912; Sørensen, 1958) that the alkali granite or an alkali granitic magma might have been produced in situ by large scale assimilation of sandstone by the augite syenitic magma. Hamilton (1964) and Ferguson (1970) stress the intrusive nature of the alkali acid rocks and argue that assimilation is not likely to have taken place in situ.

In situ differentiation of the augite syenitic magma with an oversaturated trend is also largely rejected by Hamilton (1964) and Ferguson (1970). The present author agrees with their assumption that the alkali acid rocks were formed by crystallisation of an acid magma of extraneous origin emplaced in a separate event.

\section{The relation between alkali acid rocks, pulaskite, and foyaite}

Ferguson (1970) describes the occurrences of the alkali acid rocks and of the pulaskite in area II as plug-like and sill-like, thereby weakening his earlier statement (Ferguson, 1964, p. 23): "the alkali acid rocks have intruded into the heterogeneous syenite in the form of small plugs and sills". From the discussion in Ferguson (1970) it is evident that the supposed plugs and sills are interpretations rather than evidence.

The reason for Ferguson's interpretation is probably that the field relations must be consistent with his model for the evolution of the complex (Ferguson, 1962, 1964). This model, which was based mainly on geochemical evidence, implies that augite syenite, foyaite, and the agpaitic suite formed from one batch of magma. Therefore, given the evidence that alkali quartz syenite had intruded the augite syenite, Ferguson had to assume that the acid bodies enclosed by the foyaite were of intrusive origin as well.

The pulaskite was interpreted by Ferguson (1964) as being formed by reaction between the alkali acid magma and the foyaite. Ferguson supports Ussing (1912) in stating that this reaction has usually taken place in situ. But to account for the pulaskite bodies in the foyaite Ferguson, again with the constraints imposed by his model, had to assume that in this particular area a portion of hybrid magma of pulaskitic composition was formed somewhere below the foyaite, and subsequently intruded into the foyaite in the form of plugs.

The author's field observations and the existence of pulaskite in area I and area V where no acid rocks have been observed are inconsistent with Ferguson's interpretation and support the hypothesis, discussed by Ussing (1912) and favoured by Sørensen (e.g. 1969, 1970, 1978), Emeleus \& Upton (1976) and Larsen (1976) that the pulaskite was formed indepen- 
dently of the acid magma as the uppermost of the rock units which crystallised from the agpaitic magma.

\section{Alkali acid rocks and naujaite}

All authors, except Hamilton (1964), agree that the alkali acid rocks were formed just after the augite syenite, irrespective of the hypothesis favoured for the origin of the alkali acid rocks. And if one rejects the naujaite occurrence in alkali granite as being a xenolith, for reasons given in the descriptions of area IV, there is little evidence left to support Hamilton's order of intrusion. Indeed, as Ferguson (1970) argues, there is more evidence against it.

\section{Conclusions}

It appears from the field descriptions and the discussion that, according to the author's observations, the roof zone rock units cooled in the following order: augite syenite, alkali acid rocks, pulaskite, foyaite, sodalite foyaite. The observed relations between the rock units are thus incompatible with the models presented by earlier investigators of the rocks of the roof zone: Ussing (1912), Ferguson $(1964,1970)$ and Hamilton (1964) (Table 2).

The field evidence strongly supports a model comprising at least three intrusive events separated in time: (1) augite syenitic magma, (2) alkali acid magma, and (3) agpaitic magma. The characteristic feature of the emplacement of the various magmas is the fragmentation of the present roof and subsequent subsidence of the fragments so as to form xenoliths in underlying rocks. The abandoning of Ferguson's closed-system differentiation model and the acceptance of several injections of magma has recently been advocated by Blaxland $e t a l$. (1976), Larsen (1976), and Sørensen (1978) on field and geochemical evidence.

By accepting three intrusive events in the evolution of the Ilímaussaq complex the field relations of area II appear much simpler than in the interpretation by Ferguson (1964), and the uncertainty about the position of the alkali acid rocks seems to be removed. According to Hamilton (1964) the injection of alkali acid magma probably occurred in more than one pulse. The characteristic transitional contact between the alkali granite and the pulaskite or foyaite is regarded as an assimilation effect.

\section{References}

Blaxland, A. B., Van Breemen, O. \& Steenfelt, A. 1976: Age and origin of agpaitic magmatism at Ilímaussaq, South Greenland: Rb-Sr study. Lithos 9, 31-38.

Emeleus, C. H. \& Upton, B. G. J. 1976: The Gardar period in southern Greenland. In Escher, A. \& Watt, W. S. (edit.) Geology of Greenland, 153-180. Copenhagen: Geological Survey of Greenland.

Ferguson, J. 1962: Possible mode of emplacement of the Ilímaussaq batholith. Meddr Dansk geol. Foren. 15, 144-145.

Ferguson, J. 1964: Geology of the Ilímaussaq alkaline intrusion, South Greenland. Bull. Grønlands geol. Unders. 39 (also Meddr Grønland 172,4) 82 pp.

Ferguson, J. 1970: The significance of the kakortokite in the evolution of the Ilimaussaq intrusion. South Greenland. Bull. Grønlands geol. Unders. 89 (also Meddr Grønland 190,1) 193 pp.

Hamilton, E. I. 1964: The geochemistry of the northern part of the Ilimaussaq intrusion, S.W. Greenland. Bull. Grønlands geol. Unders. 42 (also Meddr Grønland 162,10) 104 pp. 
Larsen, L. M. 1976: Clinopyroxenes and coexisting mafic minerals from the alkaline Ilímaussaq intrusion, South Greenland. J. Petrol. 17, 258-290.

Nielsen, B. L. \& Steenfelt, A. 1979: Intrusive events at Kvanefjeld in the Ilímaussaq igneous complex. Bull. geol. Soc. Denmark 27, 143-155.

Rose-Hansen, J., Karup-Møller, S., Sørensen, E. \& Sørensen, H. 1976: Uranium-rich albitites from the northern contact of the Ilímaussaq alkaline intrusion. Rapp. Grønlands geol. Unders. 85, 68 only.

Sørensen, H. 1958: The Ilímaussaq batholith, a review and discussion. Bull. Grønlands geol. Unders. 19 (also Meddr Grønland 162,3) 48 pp.

Sørensen, H. 1966: On the magmatic evolution of the alkaline province of South Greenland. Rapp. Grønlands geol. Unders. 7, 19 pp.

Sørensen, H. 1968: Über die Paragenese einiger alkalischer Gesteine in Südgrönland. Freiberger Forschungshefte C 230, 177-186.

Sørensen, H. 1969: Rhythmic igneous layering in peralkaline intrusions. An essay review on Ilímaussaq (Greenland) and Lovozero (Kola, USSR). Lithos 2, 261-283.

Sørensen, H. 1970: Internal structures and geological setting of the three agpaitic intrusions - Khibina and Lovozero of the Kola Peninsula and Ilímaussaq, South Greenland. Can. Miner. 10, 299-334.

Sørensen, H. 1978: The position of the augite syenite and pulaskite in the Ilimaussaq intrusion, South Greenland. Bull. Geol. Soc. Denmark 27, Spec. Iss., 15-23.

Steenfelt, A. 1972: Beskrivelse af pulaskit, heterogen foyait, sodalit-foyait, naujait og kakortokit på Kvanefjeldsplateauet, Ilímaussaq. Unpublished dissertation, Univ. Copenhagen, also unpubl. int. GGU rep., 58 pp.

Ussing, N. V. 1912: Geology of the country around Julianehaab, Greenland. Meddr Grønland 38, 376 pp. 